\title{
REDISCOVERY OF THE LIVERWORT FRULLANIA FRAGILIFOLIA IN POLAND
}

\author{
PIOTR GÓRSKI
}

\begin{abstract}
This paper presents a distribution map for Frullania fragilifolia (Taylor) Gottsche, Lindenb. \& Nees in Poland and a list of localities established from revised herbarium materials and literature data, and describes the rediscovery of $F$. fragilifolia in Poland almost 40 years after the last record. This liverwort was considered extinct in Poland. Twenty localities of the plant were catalogued. An attempt was undertaken to find $F$. fragilifolia in the Tatra Mts and northern Poland at selected localities known from literature data. The threat status of the species and its prospects in Poland are discussed.
\end{abstract}

Key words: Frullania fragilifolia, distribution, extinct species, Tatra Mts, Poland

Piotr Górski, Department of Botany, Poznań University of Life Sciences, Wojska Polskiego 71c, 60-625 Poznań, Poland; e-mail: peter@up.poznan.pl

\section{INTRODUCTION}

Frullania fragilifolia (Taylor) Gottsche, Lindenb. $\&$ Nees is a suboceanic-montane species endemic to Europe and Atlantic islands (Damsholt 2002). In Europe it has been recorded in Iceland, the Faroe Islands, Norway, Denmark, Sweden, Finland, Ireland, Britain, France, the Netherlands, Belgium, Germany, Poland, Switzerland, Austria, the Czech Republic, Hungary, Portugal, Spain, Corsica, Sardinia, Sicily, Italy, Slovenia, Croatia, Serbia, Bosnia \& Herzegovina, Montenegro, Romania, Bulgaria, Albania and Greece (Söderström et al. 2002; Sabovljević \& Natcheva 2006; Erzberger \& Papp 2007). Frullania fragillifolia is considered an endangered species in seven of those countries, especially in Central Europe. Currently it is believed to be extinct only in Poland (Klama 2006; Szweykowski 2006). In the 1990s it was regarded as extinct in the Czech Republic also (Váňa 1993) and currently is considered critically endangered (CR; Kučera et al. 2012).

The range of occurrence of $F$. fragillifolia in Poland comprises northwestern Poland, the foothills of the Sudetes and lower parts of the Tatras and Bieszczady Mts (Szweykowski 1958a, 2006; Szweykowski \& Koźlicka 1977). The highest concentration of localities was noted in the West Tatras. Most localities were recorded in the late $19^{\text {th }}$ and the first half of the $20^{\text {th }}$ century. This paper documents the only finding of $F$. fragillifolia in Poland in the $21^{\text {st }}$ century so far, gives its distribution in the country, and describes my attempt to rediscover the plant at selected localities known from literature data.

\section{MATERIAL AND METHODS}

The list of localities of Frullania fragilifolia in Poland was established solely from revised materials from KRAM, LBL, POZW, POZNB and WA. The distribution map is presented in the ATMOS grid square system (Ochyra \& Szmajda 1981). In 2012 and 2013 I tried to rediscover $F$. fragilifolia at six selected historical localities in the Tatra Mts and northern Pomerania (in Polish: Pomorze): the Dolina Chochołowska valley in the West Tatras (for details see no. 4 in list of localities); the Wielkie Koryciska valley in the West Tatras (see no. 4 in list); between Jaszczurówka and Cyrhla in the West Tatras (see no. 6 in list), Odargowo, N Poland (see no. 9 in list), and two localities in the Slovakian Tatras (Hazslinszky 1885; Szweykowski 1960; Šmarda 1961; Duda \& Ván̆a 1977). At each of those localities I searched for one full day. 


\section{RESULTS}

\section{DISTRIBUTION}

The literature and herbarium data give records of Frullania fragilifolia from 20 localities in Poland (Fig. 1), 15 of which are in mountains and their foothills; only four are in the Polish lowlands (Pomerania, NW Poland). The highest number of localities (12) are in the Tatra Mts, all in the lower montane belt except for two in the alpine part of the West Tatras. The altitude maximum in the Polish Tatras is at $1710 \mathrm{~m}$ a.s.1. (leg. J. Szweykowski) and the altitude minimum is at $893 \mathrm{~m}$ a.s.1. (leg. I. Szyszytowicz). In the foothills of the Sudetes it was recorded at three localities, and there is one record from the Bieszczady Mts. Eight localities were published in the second half of the 19th century, four in 1900-1950, seven in 1951-2000, and one after 2000 . The last records of $F$. fragilifolia for these localities come from 1896 for the Sudetes foothills, 1940 for Pomerania, 1956 for the Bieszczady Mts, and 1976 (2005 in this paper) for the Tatra Mts.

\section{LIST OF LOCALITIES}

Explanations: [1]-[12] - locality number, see Figure 2

SPECIMENS EXAMINED: PomorZE ZACHODNIE: [1] $\mathrm{Bb} 53$ - Smogorze (in German: Weissenbruch) near Połczyn Zdrój, Drawsko Pomorskie County, on Fagus sylvatica, 2 Oct. 1908, leg. F. Hintze, (KRAM 90820); [2] Bb 55 - [2] ca $1.5 \mathrm{~km}$ SE of Tarmno, near Barwice, Szczecinek County (in German: Tarmen, Oberbusch), on Fagus sylvatica, leg. \& det. F. Hintze, 1902, conf. K. Müller (POZW 6029; Müller 1912-1916). PogóRZE KARKONOSKIE: [3] Ea 79 - Chojnik Mt. (in German: Burg Kinnast, Kynast), leg. ? (probably G. Limpricht), (KRAM 98769; Limpricht 1876). TATRA MounTAINS: [4] Gd 58 - Dolina Chochołowska valley, forests in valley, alt. 1140 m, 15 Aug. 1882, leg. \& det. I. Szyszyłowicz (KRAM 45142; Szyszyłowicz 1885); Wielkie Koryciska valley, on Abies alba, alt. 1050 m, 2 Sept. 1967, leg. \& det. J. Szweykowski (POZW 6047); [5] Gd 59 - Dolina Strążyska valley, on Fagus sylvatica, Aug. 1877, leg. \& det. J. Krupa (KRAM 45187; Krupa 1878); Dolina Strążyska valley, alt. 932-1040 m, 17 Aug. 1881, leg. \& det. I. Szyszyłowicz (KRAM 45166); Dolina Białego valley, slopes of Mt.
Krokiew, alt. 1040 m, on Abies alba, 16 Aug. 1959, leg. \& det. J. Szweykowski (POZW 6054); Kościelisko, forests near Droga Pod Reglami route, on Abies alba, 11 April 1976, leg. J. Kornaś, det. J. Szweykowski (KRAM 9598, POZW 6056); Dolina Kościeliska valley, Stare Kościeliska glade, alt. $950 \mathrm{~m}$, on bark of Acer pseudoplatanus, 21 Sept. 2005, leg. \& det. P. Górski, conf. J. Váňa (POZNB 1101, KRAM; Fig. 1); [6] Ge 50 - Gąsienicowe równie, on Picea abies, alt. 893-993 m, 31 Aug. 1881, leg. \& det. I. Szyszytowicz (KRAM 15112; Szyszyłowicz 1885); between Jaszczurówka and Cyrhla, near Droga Oswalda Balzera road, on Abies alba, alt. 980 m, 5 Sept. 1958, leg. \& det. J. Szweykowski (KRAM 45010, POZW 6051, LBL, WA; Hepaticotheca Polonica, Fasc. VIII, Nr 199, Szweykowski 1958b, 1960); [5-6] Gd 59 or Ge50 - forests near Zakopane, alt. 854-962 m, 23 Aug. 1882, leg. \& det. I. Szyszyłowicz (KRAM 45153; Szyszyłowicz 1885); [7] Gd 68 - W slope of Mt. Jarząbczy Wierch, alt. 1710 m, 2 Sept. 1959, leg. \& det. J. Szweykowski (POZW 6052); W slope of Mt. Jarząbczy Wierch, alt. 1700 m, 24 Aug. 1960, leg. \& det. J. Szweykowski (POZW 6055). BiesZCZADY ZACHODNIE MTs: [8] Gf 68 - Valley of the Górna Solinka River, bark of old beech tree at Górna Solinka River, alt. $850 \mathrm{~m}$, 18 June 1956, leg. \& det. J. Szweykowski (POZW 6048; Szweykowski \& Buczkowska 1996).

Literature DATA. POMORZE GDAŃSKIE: [9] Ac 36 - Odargowo, Diabelski Kamień erratic, Puck County (Krawiec 1938). PoMORZE ZACHODNIE: [10] Bb $71-$ Drawsko Pomorskie (in German: Dramburg), precise location not given (Koppe \& Koppe 1940). PoGÓRZE KARKONOSKIE: [11] Ea 78 - Szklarska Poręba, Huty (in German: Josephinenhütte; Limpricht 1876); [12] Eb 70 - Góra Witosza Mt. near Staniszów (in German: Prudelberg; Limpricht 1876).

\section{NEW LOCALITY}

The new locality of Frullania fragilifolia, found 21 September 2005, is in the Stare Kościeliska glade, Dolina Kościeliska valley, West Tatra Mts. A sparse population of this liverwort grew on the bark of a huge maple tree along the main valley trail. The locality is in an almost open area but its epiphytic flora is exceptionally abundant and species-rich. Besides $F$. fragilifolia there were, for example, F. dilatata (L.) Dumort., Metzgeria furcata (L.) Dumort., Porella platyphylla (L.) Pfeiff., Hypnum cupressiforme Hedw. and Leu- 

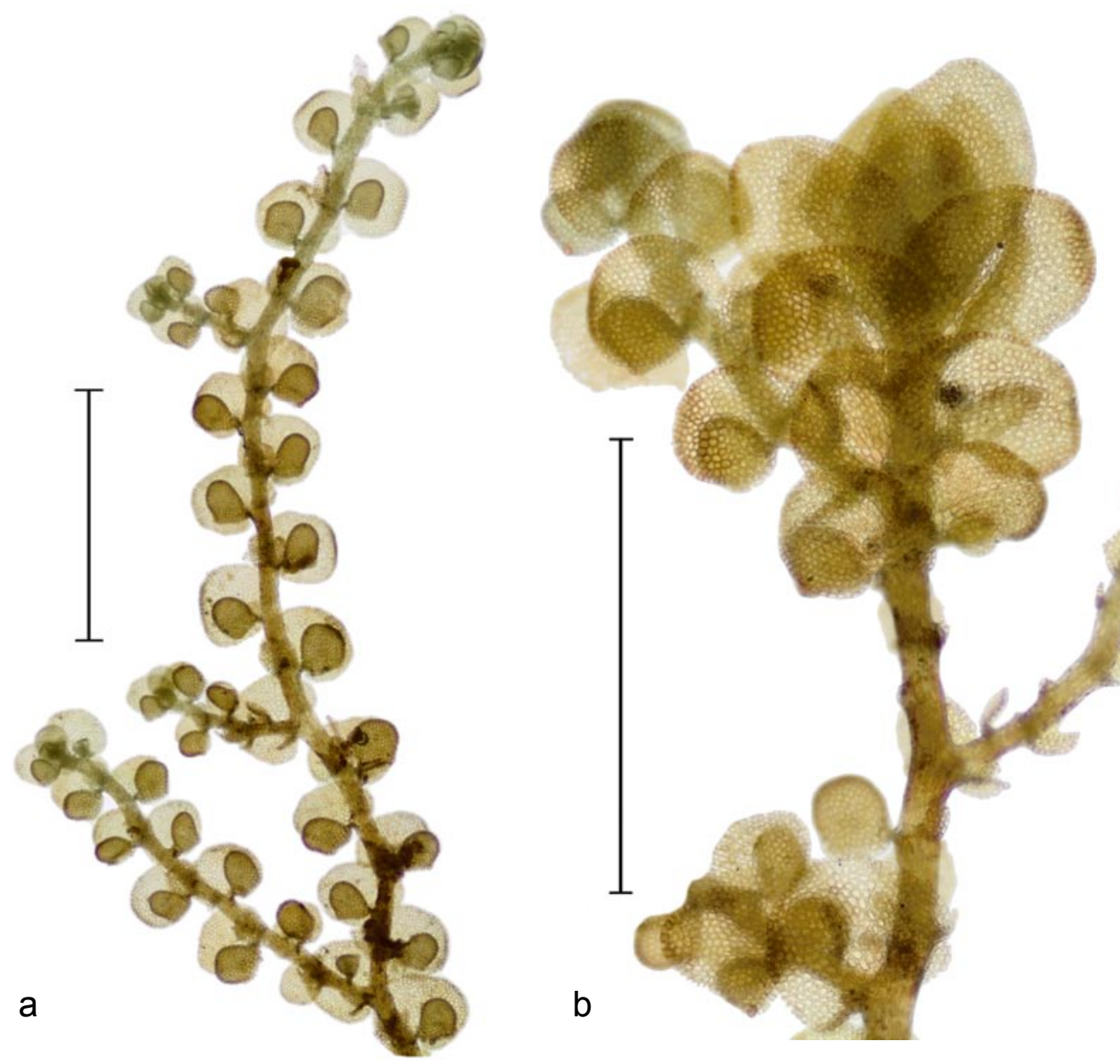

Fig. 1. Frullania fragilifolia (Taylor) Gottsche, Lindenb. \& Nees. (all from POZNB 1101, leg. P. Górski, 2005): ventral (a) and dorsal (b) views; scale bars $=1 \mathrm{~mm}$.

codon sciuroides (Hedw.) Schwägr. Other data concerning the finding are given under no. 5 on the list.

\section{FRULLANIA FRAGILIFOLIA AT HISTORICAL} LOCALITIES

\section{TATRA MTS (POLISH AND SLOVAKIAN PARTS)}

In the Polish Tatra Mts I searched three localities of Frullania fragilifolia given in the literature and did not find the liverwort at any of them. These localities are in areas of Tatra National Park currently under forestry management. The forest stand is decimated and the undergrowth is partially destroyed. In some places the natural beech forest with fir has been supplanted by managed forest with spruce. The epiphytic flora on the bark of beech and fir is sparse. The common liverworts are Metzgeria furcata, Frullania dilatata, Ptilidium pulcherrimum (Weber) Vain., Lophocolea heterophylla (Schrad.) Dumort. and Radula complanata (L.) Dumort.; Porella platyphylla is rare as an epiphyte. On the other hand, rare epiphytes still grow in preserved fragments of beech forests near Cyrhla (at Droga Oswalda Balzera road). During the search for F. fragilifolia in 2012 there 


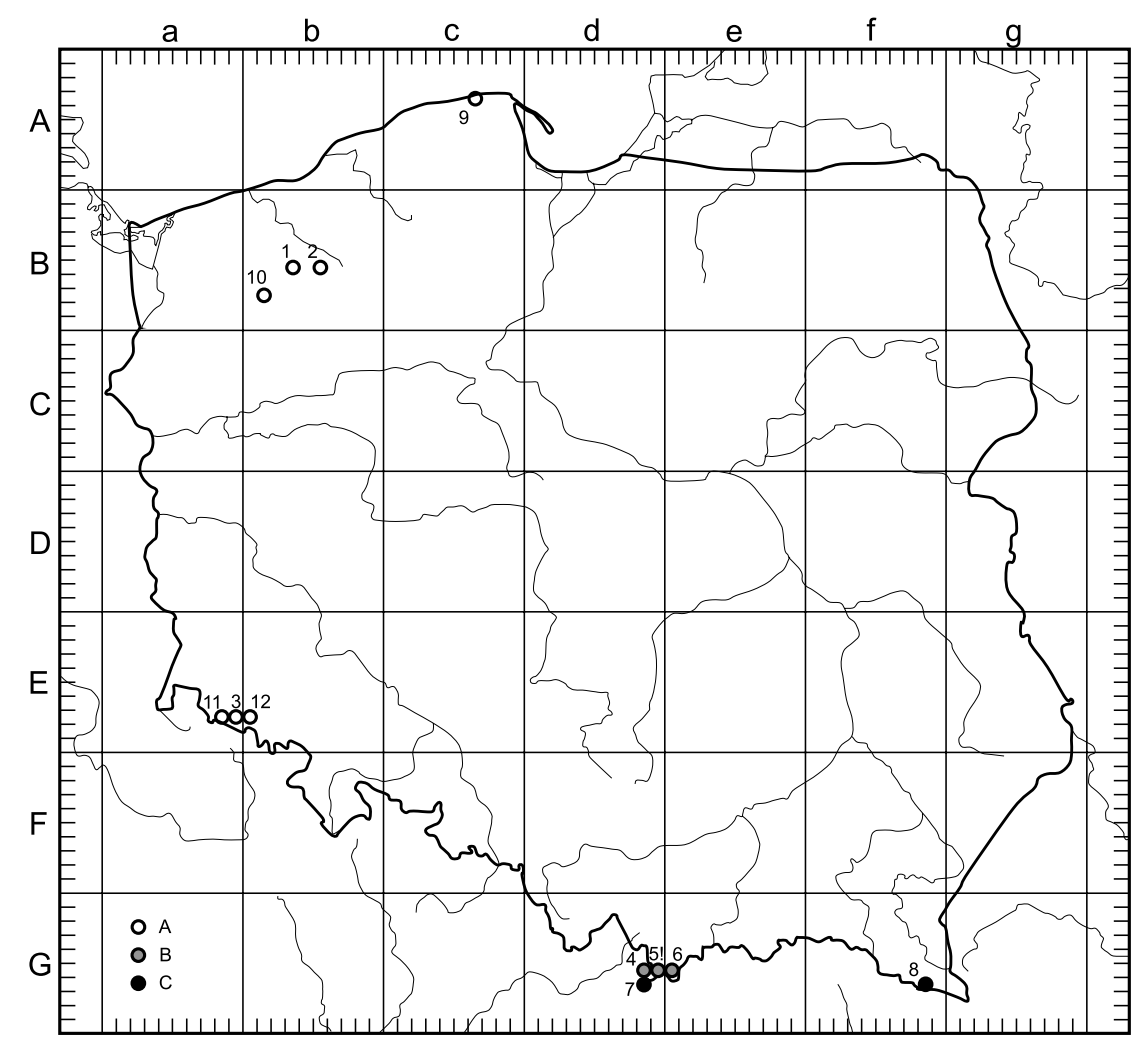

Fig. 2. Distribution of Frullania fragilifolia (Taylor) Gottsche, Lindenb. \& Nees in Poland: 1-8 - localities with specimens examined, 9-12 - literature data; ! - new locality; A - localities found before 1950, not confirmed later, B - localities found before 1950, confirmed later, C - localities found after 1950, not confirmed later.

I found the second locality of Metzgeria violacea (Ach.) Dumort. in the Polish Tatra Mts; the first was published by Mickiewicz (1965). Its population is extremely small, however, and limited to a single tree.

In the Slovakian Tatras $F$. fragilifolia was recorded from two localities in the Belianskie Tatry Mts: Zdiarske sedlo pass (Hazszlinszky 1885) and the Dolina Hučava valley near Sumivý prameň, alt. 880 m (13 July 1957, leg. J. Szweykowski, POZW 6037; Szweykowski 1960). The plant does not grow anymore at those two localities. Since the last records of the species in the Belianskie Tatry Mts, almost 130 years after Hazslinszky's and 50 years after Szweykowski's records, the forest stands in the lower montane belt have been dramatically altered. Zdiarske sedlo pass is now almost entirely deforested. The remaining forested areas are spruce monocultures. In the Dolina Hučava valley there are still some mighty fir trees but they are surrounded by managed forest or a wide forestless area reaching the Tatra foothills. The epiphyte flora of fir near the spring of Sumivý prameň is insignificant. It is even difficult to find Ptilidium pulcherrimum.

\section{NORTHERN POLAND}

The locality from Northern Poland is the only one from lowland records of Frullania fragilifolia with a very precisely indicated locality. It was described by Krawiec (1938) on an erratic named Diabelski Kamień (Devil Rock), ca $1 \mathrm{~km}$ NE of Odargowo village (near Baltic shore, Krokowa municipality, Puck County). Krawiec even provided a photograph of the rock (Fig. 3a), 

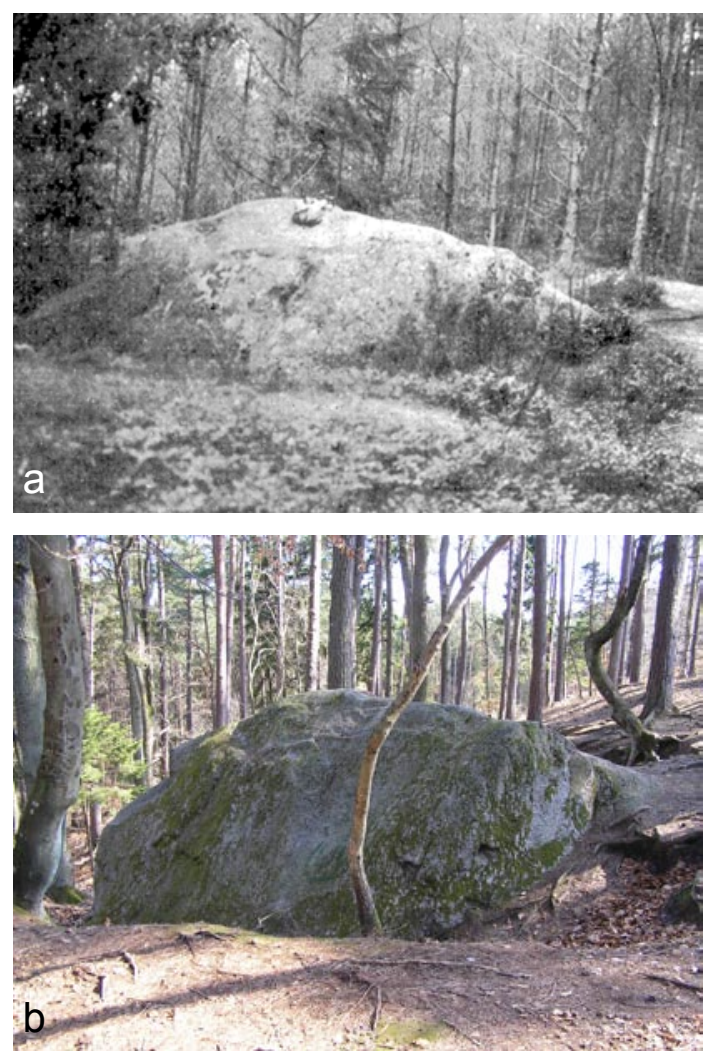

Fig. 3. Diabelski Kamień (Devil Rock) erratic near Odargowo (Pomerania, N Poland), a previous locality of Frullania fragilifolia: in the photograph published by F. Krawiec in 1938 (a); and at present without liverworts (b), photograph taken on 22 April 2013 by P. Górski.

to show its impressive size but also to emphasize the presence of $F$. fragilifolia. I recatalogued the liverworts of the rock on 22 April 2013 (Fig. 3b). Unfortunately, F. fragilifolia was not growing on the rock by then. Other liverworts reported by Krawiec (1938), Frullania dilatata and Ptilidium pulcherrimum, were not present either. The predominant species was the moss Hypnum cupressiforme, with an admixture of Hedwigia ciliata (Hedw.) P. Beauv. Nor was $F$. fragilifolia present in the beech epiphyte flora of the surrounding beech-pine forest (Luzulo pilosae-Fagetum). The abundant species were Frullania dilatata, Radula complanata and Metzgeria furcata. I searched for $F$. fragilifolia on other erratic rocks near the mentioned Devil Rock. A group of these objects can be found $c a 9 \mathrm{~km} \mathrm{SE}$ of Odargowo, near Świecino village (Wejherowo Forest Inspectorate, Domatowo forestry unit). All the rocks were in a managed forest in acidic Luzulo pilosae-Fagetum beechwood. Some descriptions can be found in the mentioned study (Krawiec 1938). I did not find $F$. fragilifolia on the rocks and beech trees there either. Among the liverworts, Plagiochila porelloides (Torrey ex Nees) Lindenb. was the most frequent species, and there was one station of Jamesoniella autumnalis (DC.) Steph.

\section{DISCUSSION}

Apparently Frullania fragilifolia is an extinct species in the Polish lowlands. No one has seen the plant since 1940, although hepaticological studies have been made in Pomerania in the intervening time (Szweykowski \& Koźlicka 1966, 1969; Górski 2010). Szweykowski and Buczkowska (1996) noted its extinction in the Bieszczady Mts, even though in the 1950 s it was a frequent component of the beech epiphytic flora on that massif. It seems that the Tatra Mts are now the plant's only site in Poland. The beech (with fir) forests or spruce-fir forests of the lower montane belt have undergone enough transformation to push the plant to the verge of extinction. This applies to both the Polish and Slovakian Tatras. Significant changes took place on the foothills on the north side of the Polish West Tatras and the Belianskie Tatry Mts. The absence of $F$. fragilifolia on limestone in the lower montane belt is of interest. This phenomenon is known for other beech epiphytes, Porella platyphylla or Frullania tamarisci (L.) Dumort., which currently are more often found on rocks than on tree bark (Zubel \& Stebel 2008; personal data). The presence of $F$. fragilifolia in the alpine belt of the Tatras on crystalline schists indicates that its localities are stable and safe there. The Tatra Mts lack a detailed catalogue of liverwort flora, so it is difficult to estimate the resources of the species on higher rock shelves. Many liverworts recorded earlier at higher locations in the Tatra Mts are still found today at the same localities [e.g., Tetralophozia setiformis (R. M. Schust.) Schljakov, Orthocaulis binsteadii (Kaal.) 
H. Buch, Scapania crassiretis Bryhn, Odontoschisma francisci (Hook.) L. Söderstr. \& Váňa, Moerckia blyttii (Moerch) Brockm., Nardia breidleri (Limpr.) Lindb.; personal data]. Under the current IUCN endangerment categories, Frullania fragilifolia should be considered critically endangered (CR) in Poland.

ACKNOWLEDGEMENTS. I am grateful to Professor Jiří Váňa (Charles University, Prague, Czech Republic) for revision of my herbarium specimen from the Tatra Mts, Dr. Anna Rusińska (Adam Mickiewicz University, Poznań) for valuable suggestions on the manuscript, and the Curators of KRAM and POZW for loan of collections. This study was funded in part by the Polish Ministry of Science and Higher Education through grant no. NN 304028539.

\section{REFERENCES}

DAMSHOLT K. 2002. Illustrated Flora of Nordic Liverworts and Hornworts. Nordic Bryological Society, Lund.

DudA J. \& VÁŇA J. 1977. Die Verbreitung der Lebermoose in der Tschechoslowakei-XXI. Čas. Slezs. Mus., Ser. A, Hist. Nat. 26: 35-54.

ERZBERGER P. \& PAPP B. 2007. New and noteworthy bryophyte records from Montenegro and Serbia. Wildenowia 37: 339-351.

GÓRSKI P. 2010. A contribution to the liverwort flora of the Drawsko Lake District (Western Pomerania, Poland). Botanika-Steciana 14: 19-26.

HAZsLinszKY F. 1885. A Magyar Birodalom Moh-Flórája. Királyi Magyar Termé-szettudományi Társulat, Budapest.

KLAMA H. 2006. Red list of the liverworts and hornworts in Poland. In: Z. MIREK, K. ZARZYCKI, W. WOJEWODA \& Z. SZELĄG (eds), Red list of plants and fungi in Poland, pp. 21-33. W. Szafer Institute of Botany, Polish Academy of Sciences, Kraków.

Koppe F. \& KopPE K. 1940. Vierter Beitrag zur Moosflora der Grenzmark Posen-Westpreußen. Grenzmärkische Heimatblätter (Schneidemühl) 6(3): 1-80.

KRAWIEC F. 1938. Die epilithische Flora der erratischen Blöcke Westpolens. Prace Komis. Mat.-Przyr., Ser. B, Nauki Biol. 9(2): 1-254 (in Polish with German summary).

KRUPA J. 1878. Wykaz mchów zebranych w Tatrach w sierpniu 1877 r. Spraw. Komis. Fizyjogr. 12: 149-157.

KUČERA J., VÁŇA J. \& HRADíLEK Z. 2012. Bryophyte flora of the Czech Republic: updated checklist and Red List and a brief analysis. Preslia 84: 813-850.
LiMPRICHT G. 1876. Die Lebermoose. In. F. COHN (ed.), Kryptogamen-Flora von Schlesien. 1: 225-352. J. U. Kern's Verlag, Breslau.

MiCKIEWICZ J. 1965. Bryophytes in epiphytic beech associations. Monogr. Bot. 19: 3-82 (in Polish with English summary).

MÜLLER K. 1912-1916. Die Lebermoose Deutschands, Oesterreichs u. d. Schweiz mit Berücksichtigung der übrigen Länder Europas. In: Dr L. Rabenhorst's Kryptogamen Flora von Deutschland, Österreich und der Schweiz. 2 Aufl. 6(2). Verlag von Edouard Kummer, Leipzig.

OCHYRA R. \& SZMAJDA P. 1981. La cartographie bryologique en Pologne. In: J. SZWEYKOWSKI (ed.), New perspectives in bryotaxonomy and bryogeography. Uniwersytet im. Adama Mickiewicza w Poznaniu, Seria Biologia 20: 105-110.

SABovljević M. \& NATCHEVA R. 2006. Check-list of the liverworts and hornworts of Southeast Europe. Phytologia Balcan. 12(2): 169-180.

S̆MARDA J. 1961. Notes on the distribution of liverworts in Czechoslovakia VI. Biologické Práce, Bratislava 7(1): 5-45 (in Czech with English, German and Russian summaries).

SÖDERSTRÖM L., URMI E. \& VÁŇA J. 2002. Distribution of Hepaticae and Anthocerotae in Europe and Macaronesia. Lindbergia 27: 3-47.

SzWEYKOWSKi J. 1958a. Prodromus Florae Hepaticarum Poloniae. Prace Komis. Biol. 19: 1-600.

SzWEYKowSKi J. 1958b. Hepaticotheca Polonica. Fasc. VIII, nr 176-200. Hepaticae Tatrenses. Polska Akademia Nauk, Poznań.

SZWEYKOWSKI J. 1960. Floristic investigations on the liverwort flora of the Tatry Mountains. Prace Komis. Biol. 21(3): 3-92 (in Polish with English summary).

SzWEYKOWSKI J. 2006. An annotated checklist of Polish liverworts and. Biodiversity of Poland. 4. W. Szafer Institute of Botany, Polish Academy of Sciences, Kraków.

SZWEYKOWSKI J. \& BUCZKOWSKA K. 1996. Liverworts of the Bieszczady Zachodnie Range (Polish Eastern Carpathians) - a vanishing relict boreal flora. Fragm. Florist. Geobot. 41(2): 865-934.

SZWEYKOWSKi J. \& KoŹLICKA M. 1966. Liverworts (Hepaticae) of Wolin and Uznam islands (NW. Poland). Badan. Fizjogr. Polsk. Zachodn., B 18: 155-178.

SzWEYKOWSKi J. \& KoźLICKA M. 1969. A contribution to the hepatic flora of Pomerania (NW. Poland). Badan. Fizjogr. Polsk. Zachodn., B 23: 125-149 (in Polish with English summary).

SZWEYKOWSKi J. \& KoŹLICKA M. 1977. H. 241. Frullania fragilifolia Taylor. In: J. SzWEYKOWSKI \& T. WOJTERSKI (eds), Atlas of geographical distribution of spore plants in Poland. Series IV. Liverworts (Hepaticae). 9: 25. Polska 
Akademia Nauk, Państwowe Wydawnictwo Naukowe, Warszawa - Poznań.

SZYSZYŁOWICZ I. 1885. O rozmieszczeniu wątrobowców w Tatrach. Spraw. Komis. Fizjogr. 19: 4-125.

VÁŇA J. 1993. Preliminary list of threatened bryophytes in the Czech Republic. 1. Liverworts (Hepaticophyta) and hornworts (Anthocerotophyta). Preslia 65: 193-199 (in Czech with English summary).

Zubel R. \& STEBel A. 2008. Occurrence of Frullania tamarisci (Marchantiophyta, Frullaniaceae) in the Polish Carpathians. In: A. STEBEL \& R. OCHYRA (eds), Bryophytes of the Polish Carpathians, pp. 257-266. Sorus, Poznań.

Received 30 April 2013 